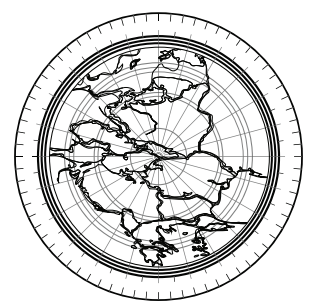

\title{
Bombs in Vilnius: Radicalization of Antisemitic Attitudes and Practices Before World War II
}

DOI: https://doi.org/10.11649/sn.2500

\author{
Natalia Judzińska \\ Institute of Slavic Studies, Polish Academy of Sciences \\ https://orcid.org/0000-0002-2994-6102 \\ e-mail: natalia.judzinska@gmail.com
}

\begin{abstract}
On the eve of the Holocaust Poland saw enormous acts of antisemitic violence in every aspect of everyday life. This article proposes an analysis of antisemitic acts and actions that under Polish rule took place in Vilnius. In early 1937, the city witnessed a wave of antisemitic bomb attacks. Vilnius violence is set in the context of pogroms in other cities, but it remains an example and a specific model of unconditional radicalization of both nationalist attitudes and practices among Poles from different classes and social strata. The study focuses on the participation of students, prospective or actual members of the intelligentsia, in this "festival of violence", and analyzes those events within the concepts of pogrom and Victor Turner's social drama.
\end{abstract}

Keywords: antisemitism; far-right movement; terrorism; university; collective violence; interwar period

This work was supported by a grant from the National Science Centre, Poland (decision no. 2018/31/N/HS3/00947). No competing interests have been declared.

Publisher: Institute of Slavic Studies, Polish Academy of Sciences.

This is an Open Access article distributed under the terms of the Creative Commons Attribution 3.0 PL License (creativecommons.org/licenses/by/3.0/pl/), which permits redistribution, commercial and non-commercial, provided that the article is properly cited. (c) The Author 2021. 


\section{Introduction}

The anti-Jewish violence in late 1936 and early 1937 in Vilnius followed a specific pattern which Victor Turner calls a "social drama" (Turner, 1974). As he notes, during a crisis, social events recreate a certain model ${ }^{1}$ of behavior, typical of the majority group. Joanna Tokarska-Bakir frames the anti-Jewish violence in the construction of the social drama as a pogrom, first in her monograph Okrzyki pogromowe (Pogrom Cries) (Tokarska-Bakir, 2012, pp. 167-176, 2017, pp. 273-304), and later in Pod klatwa [Cursed] (Tokarska-Bakir, 2018). By setting the Vilnius events in the context of other pogroms taking place in Poland at that time (although some of them did not involve documented fatalities) ${ }^{2}$ and by structuring these events, we obtain a picture of a type of pogrom-like collective violence initiated and committed among others by students, in other words, by prospective members of the intellectual elite of the country.

In her study on collective violence and terrorism as its type, Roberta Senechal de la Roche states that terrorism is "nongovernmental, unilateral violence with a high degree of organization and a logic of collective liability" (Senechal de la Roche, 2004, p. 2). I propose an analysis that frames a series of bomb attacks in Vilnius in early 1937 as an act of terror, a radical form of antisemitic violence, and a symptom of radicalization of antisemitic attitudes among non-Jewish Poles. I will highlight the involvement of university students in those events and try to show that the violence began at the Stefan Batory University (hereafter SBU), spread all over the city, and was followed by a series of bomb attacks between January and March 1937. The article is divided into three parts. In the first two, I present the material and bring up the historical context. Then I focus on both university and legal proceedings and trials. The final part contains a brief description of the aftermath of those events and conclusions.

Writing about the wave of antisemitic bomb attacks that swept through Vilnius in early 1937 from the historical perspective, Aleksander Srebrakowski calls his article "a documentary chronicle" (Srebrakowski, 2018). Indeed, it mainly contains a chronicle of events based on press articles, and points to the need to develop their analysis. In the daily reports of the Vilnius voivodship police from 1937, information on political cases (including antisemitic violence) was considered confidential and was not disclosed, hence the difficulty in finding detailed descriptions of those events in the press. The interwar period was characterized by serious concerns about potential internal tensions, and political cases

\footnotetext{
1 The four phases of the social drama are: breach (understood as a violation of fundamental principles of the community), crisis (manifested by spreading rumors around the city and gathering pogrom crowds), redressive action (i.e. attempts to introduce solutions that could stop the violence), and reintegration, or, in a critical situation, the irreparable schism. Although in proceedings before the court the redressive actions consist in apprehending the perpetrators and punishing them, in the case of events at Vilnius University these measures were not fully used: the fines imposed were disproportionately low in relation to the committed acts.

2 By "no fatalities" I mean no documented casualties. The number of people who lost their physical or mental health (or both), or decided to commit suicide as a result of these events, remains unknown.
} 
appeared in separate secret reports. Nevertheless, their traces can be found in the police reports kept at the Lithuanian Central State Archives (LCVA) in Vilnius.

The time period covered in this article is connected with the key moment in the functioning of the university in the context of the implementation of the "ghetto benches", a system of racist segregation introduced in most universities in interwar Poland. The participation of Polish students, who were the prospective intellectual elite not only of Vilnius, but of the entire country, turned out to be crucial in causing acts of violence not only on university premises, but especially outside them. Indeed, the incidents I describe not only originated at the university: in press articles and police reports, students appear as initiators of violence and as the key defendants in the Vilnius bombing trial.

Between January and March, Vilnius saw the explosion of fourteen bombs. Three more devices were planted but did not explode. All the targets where Jewish businesses or private houses, including the house of a university professor. Fortunately, no one died. As it shortly turned out, a terrorist group was responsible for all the attacks: Północno-wschodnia grupa terrorystów-antysemitów (The Northeast Group of Terrorists-Antisemites), as they called themselves in an offensive letter addressed to the police ("Proces o zamachy petardowe", 1938, p. 4). All of the six people involved in the bombings were members or former members of various nationalist groups, and three of them were closely connected with the university. All of them were caught, and the trial was held a year later. Maria Świechowska, an unemployed teacher and a former SBU student, was sentenced to two and a half years in prison, Władysław Naborowski - one year and a half, Bolesław Ostanówko - one year, Albert Kropiwnicki - one year. Jan Drawnel and Zygmunt Kurczewski were acquitted ([w], 1938b, p. 5). The trial of two other defendants, Alicja Olszewska and her son Waldemar, was separated and postponed. I identify their acts of terror as an element of the radicalization of antisemitic attitudes.

\section{Who Gets a Bomb and Who Gets a Firecracker?}

In their reports, both the police and the press used the word "firecracker" (petarda) instead of "bomb" (bomba). "Firecracker" belongs to a completely different semantic field than a "bomb" or "mine" (mina): it is connected with the sense of fun rather than fear. The process of trivializing various types of violence and weapons used to cause damage underestimates the real danger and blurs the exact scale of the violence. In police reports on the bombings, which I quote below, we can find mainly the information about "firecrackers". The first explosion took place on 14 January:

On 14th [of January] at 0.45 a.m., Dawidson Rachmiel, resident at 61, Żwirki i Wigury Street [today Dariaus ir Gireno g.], notified the 2 nd Police Station by phone that on that day at 0.40 an explosion had occurred at the front door of his grocery store. A police patrol was sent to the scene immediately and found out that a firecracker had exploded 
at the front door. As a result of the explosion, a wooden porch was damaged, the boards of which were scattered in a radius of over 10 meters. In the entrance door, the sheet metal fittings were torn out, and in the inner door, the lower panel was torn out. The upper windows above the door were thrown across the room into the kitchen. 31 glass panes fell out in the house. In the neighboring house, no. 7, owned by Bursztejn Icek, 4 glass panes fell out. In the bakery of Stemplewski Judel, located on the opposite side of the street, 7 glass panes fell out. (Police report, Lietuvos centrinis valstybės archyvas, hereafter LCVA, F. 89, ap. 5, b. 221, k. 719)

\section{The report continues as follows:}

On 14.01 at 6 a.m., Bombul Franciszek, caretaker, residing at 28, Mickiewicza Street [today Gedimino], in the same house, in the corridor connecting the gate with the main entrance, found a time mine. The package containing the mine was inscribed: Lignoryt Katowice. Inside the package was a watch and 2 batteries. According to the statement made by Bombul Franciszek, the watch on the time mine was set for 11 o'clock in the morning. (Police report, LCVA, F. 89, ap. 5, b. 221, k. 719)

Here, the police officer used the word "mine" certainly because of the presumed industrial origin of the explosive. The word "mine" occurs in police reports only once. A few days later, the next bomb exploded:

On 18th [of January] at 3.13 [a.m.], there was an explosion of a time firecracker planted in the opening in the basement of the house no. 1 at Poznańska [today Palangos] Street in Vilnius, which houses the editorial office of the Wilner Tog newspaper. As a result of the explosion, several dozen glass panes fell out of the windows of the printing house and from the windows of the house on the opposite side of the street, and the plaster in the cellar opening fell off. There was no other damage or human causalities. The explosion site was secured. (Police report, LCVA, F. 89, ap. 5, b. 221, k. 711)

This was another attack on the editorial office of the Wilner Tog, a daily published in Yiddish, within two months. On the previous occasion, windows were broken during student antisemitic riots in the fall of 1936; I will discuss those events further below. The information about the bomb in the editorial office appeared on the front page of the paper ([א], 1937, p.1). Later on the same day there was another attack:

On 18th [of January] a caretaker of Association "Klucze", located at Zamkowa [today Piliès] Street, Mosiejko Stanisław, living at 6, Obozowa [today Šeimyniškių] Street, informed the constable on duty, Zbrożek Walenty from the 3rd Police Station, at the intersection of Zamkowa and Magdaleny [today Piliès and B. Radvilaitès] streets, that in front of Rabinowicz's shop at 8, Wielka [today Didžioji] Street there was a cardboard box which he thought was suspicious, as a clock ticking had been heard from the box. Zbrożek went there, took the cardboard box to a safe place, at [the corner of] [Święto]Jańska [today Šv. Jono] and Zamkowa streets, notifying the duty officer of the Headquarters of the City of Vilnius about it. The Commandant of the City of Vilnius cut the connections of the watch with the explosive, thus neutralizing the firecracker. (Police report, LCVA, F. 89, ap. 5, b. 221, k. 711) 
It was the second neutralized bomb, but the attacks did not cease. The next day, Jewish homes and businesses were targeted again:

On 19th [of January] at 11.30 p.m., an unknown perpetrator threw a low power explosive firecracker, constructed from an iron tube and fitted with a fuse, at the door of a shop located in the basement at 5, Dąbrowskiego [today Vienuolio] Street, belonging to Chajet Czerni, living in the same house. As a result of the explosion, the lower wing [lower panel] of the entrance door was damaged, and 2 door windows fell out. The perpetrator threw this firecracker while probably driving a horse carriage. (Police report, LCVA, F. 89, ap. 5, b. 221, k. 709)

The bombs were planted, or, as in the example above, thrown at places where they were supposed to explode. The timing of the attacks in various parts of the city suggests that they were intended not only to cause damage to property but also to harm people. A newspaper report of the trial points that "it was only a stroke of luck that no one was killed in the attacks, and only the defendants suffered consequences" "Proces bombiarzy endeckich", 1938, p. 3). As we can see in the next quotes, the devices planted in residential houses (in the corridors or at the doors of apartments) usually exploded in the late evenings, early mornings, or during the day (for example, the bombing of Franciszek Bombul's, Salomon Załb's, Boruch Brudner's, Rabbi Rubinstein's homes). Those targeting business premises usually exploded at night. A few days later there were next bombs:

On 22nd [of January] at 13.15, in the staircase of the house no. 42 at Mickiewicza Street [today Gedimino] in Vilnius, a primitive grenade, constructed from a piece of pipe and filled with gunpowder, exploded at the door of the apartment of Salomon Załb, the owner of a pharmacy located in that house. Iron shards scattered across the corridor causing no harm. (Police report, LCVA, F. 89, ap. 5, b. 221, k. 700)

Further on, the same report reads as follows:

On 22nd [of January] at 22.35, the house janitor at 37, Subocz [today Subačius] Street in Vilnius, Antoni Hryhorowicz, informed the 2nd Police Station that he had found a package with explosives and a smoldering wick in the hallway of the house. Hryhorowicz extinguished the wick and threw the package into the snow in the yard. (Police report, LCVA, F. 89, ap. 5, b. 221, k. 700)

It was another foiled attack. Meanwhile, at the beginning of February, the rector of SBU Witold Staniewicz decided to reopen the university after almost three months of keeping it closed due to the antisemitic violence which had occurred in university buildings. However, this long closure did not stop the violence and further "incidents" took place, both inside and outside the university. At that time, police did not consider associating the explosions with the antisemitic violence that started at the university. The bomb attacks continued:

2 February at 3.40 [a.m.], a time firecracker exploded, planted by unidentified perpetrators at Turgiel Hirsz's grocery store, located in the house no. 9 at Mała Pohulanka [today Kalinausko] in Vilnius. As a result of the explosion, 7 windows in the store and 
4 panes in the other windows of the house fell out. (Police report, LCVA, F. 89, ap. 5, b. 221, k. 687)

What followed a few days later was another attack:

4th [of February] at 11.45, a firecracker exploded at the door of Boruch Brudner's apartment at 6, W[ielka] Pohulanka [today Basanavičiaus], app. 21. As a result of the explosion, the entrance door was damaged and several panes in the staircase window fell out. The cost of damage amounts to 10 złotys. There were no causalities. The firecracker was made from an elbow of a water pipe. The perpetrators are not known. (Police report, LCVA, F. 89, ap. 5, b. 221, k. 622)

And a few days later the next bomb went off:

8th [of February] at 19.30, a firecracker exploded in the house no. 9 at Portowa [today Pamėnkalnio] Street in Vilnius. The firecracker, constructed from a water pipe elbow [and fitted] with a fuse, was placed on the 1st floor between the double doors leading to the apartment of Rabbi Rubinsztejn Izaak, Member of Parliament. As a result of the explosion, the door was damaged and 6 windowpanes fell out. There were no human causalities. The cost of damage does not exceed 50 złotys. An investigation is underway. The perpetrators have not yet been identified. Today MP Rubinsztejn is going to Warsaw to intervene. (Police report, LCVA, F. 89, ap. 5, b. 221, k. 670)

This was another attack that members of the Rubinstein family had experienced in a few months. Before the bombing, when the university was engulfed in a wave of antisemitic violence, the son of Member of Parliament Isaac Rubinstein was one of the assaulted academic lecturers. The right-wing daily Dziennik Wileński informed: "Jews were also removed from the green at 23, Zakrętowa Street [today Čiurlionio], but two lecturers, Haifes and Rubinsztejn, were severely beaten, and noticeboards were destroyed" ("wu", 1936, p. 2). Kurjer Wileński reported: "In the evening hours, SBU assistant professor of physiology Dr. Rubinsztejn, the son of Rabbi Rubinsztejn MP, was allegedly beaten by a group of students on the corner of Sierakowskiego [today Sierakausko] and Zakrętowa [today Čiurlionio] streets" (A.G., 1936, p. 5). I will discuss November violence later on in the article. In the middle of February, bombs were planted in the next locations:

13th [of February] at 20.20, in the stairwell of the house no. 7 at Jagiellońska [today Jogailos] Street, at the door of apartment no. 3, occupied by Parnes Borys, former President of the [Vilnius] Jewish Community, a firecracker exploded, planted by unknown perpetrators. As a result of the explosion, the door was damaged and the glass in the staircase windows fell out. There were no human causalities. (Police report, LCVA, F. 89, ap. 5, b. 221, k. 602)

Five days later Vilnius saw another blast:

18th [of February] at 21, on the road next to the house no. 20 at Ciasna [today Ankštoji] Street, a crude grenade made of a water pipe exploded without causing any harm. An investigation is underway. (Police report, LCVA, F. 89, ap. 5, b. 221, k. 651) 
During this time, for almost two months, the police were unable to apprehend anyone responsible for the explosions. The limited interest of the Polish press in the bombings indicates that finding the perpetrators was not a priority. The situation did not change until the second half of March, when a pure coincidence led to a breakthrough in the investigation.

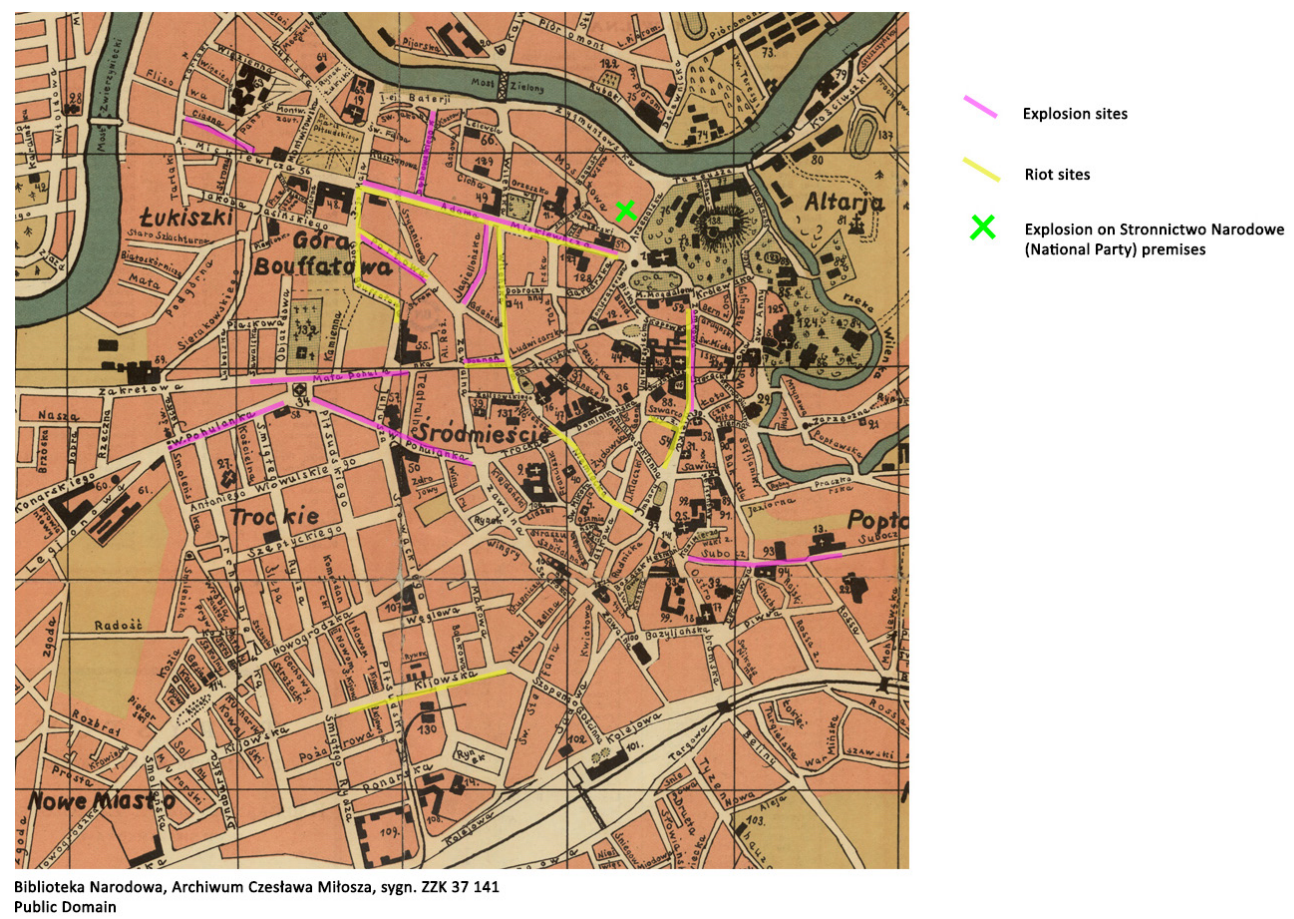

Fig. 1. Sites of explosions and riots on the city map from 1936.

\section{Developments at the University}

From November 1936 onwards, the SBU authorities noted increasing violence against Jewish students. In his letter to Wojciech Świętosławski, the Minister of Religious Denominations and Public Education, the rector of SBU, Władysław Jakowicki, reported:

As every time in the last five years, already in the first days of November this year there was an atmosphere of excitement and anxiety among the academic youth, which intensified with the anniversary of the death of Stanisław Wacławski, killed during the violent student riots on 10 November 1931. (Władysław Jakowicki, LCVA, F. 175, ap. 1(I)A, b. 545, k. 1)

Stanisław Wacławski was a first-year law student at SBU (Mrzygłód, 2021). During the eruption of anti-Jewish violence in November 1931, he died in hospital after being hit in 
the head with a stone in a street fight. ${ }^{3}$ From 1931 onwards, the death of Wacławski became a pretext to "defend Polishness" in its national, and not civic, meaning by initiating riots and forcibly removing Jewish students from university premises. The antisemitic violence that returned every November became a ritual whereby the new students entered the Polish academic community, and it was repeated by Polish youth every year (Aleksiun, 2012, 2014, 2016; Judzińska, 2020; Natkowska, 1999; Rudnicki, 1993, 2008; Żyndul, 1994). Wacławski's death anniversary was also a signal for defenders to start attacks. One of the self-made leaflets found in a police search at the home of a suspect of antisemitic violence in November $1937^{4}$ stated: "10 November is the 6th anniversary of the brutal murder committed on our fellow student Stasiu Wacławski by Jewish thugs" (Franciszek Ditz, LCVA, F. 129, ap. 2, b. 1296).

In the academic year 1936/1937, the university was closed for three months (from 12 November 1936 to 6 February 1937) due to the anti-Jewish violence. During those three months, an illegal demonstration of Christian students took place, a student dormitory at Bouffałowa Street (today Tauro) was occupied by non-Jewish students for over a week, and the windows of the rector's private house were broken. There were also two separate meetings of the university authorities with representatives of Christian youth associations - those with the "Aryan paragraph" in their statutes (constitutions) - and Jewish student unions, where efforts were made to settle "the issue of taking seats in lecture halls", which finally led to the rector's resignation. On 1 December 1936, Isaac Rubinstein submitted a parliamentary question on violence at the university in Vilnius. ${ }^{6} \mathrm{He}$ asked whether the officials knew about antisemitic actions that where ongoing both at the SBU and in the city, and if so, whether they planned to do anything to make Jewish students and

3 The riots were triggered by the closure of the dissecting room after representatives of the non-Jewish youth asked the lecturer whether Jewish students worked on the bodies of Christian newborns. Fearing an escalation of physical violence at the university, the professor closed the lab and riots spread to the streets, where Stanisław Wacławski died from a blow to the head with a stone. Apart from the death of Wacławski, the result of the riots was that several dozen people were wounded, among them many Jews, there was property damage, shops were looted, and the university was closed for several weeks. The events were so widely echoed that Wacławski's funeral was used as a political event aimed at drawing attention to the alleged necessity, if not of spatial separation, then certainly of significantly limiting the possibilities of participation of Jews in public life. Wacławski's tombstone became a monument to those events: apart from the name and the date of birth and death, it contains the inscription "Fell in the fight for Great Poland / stoned by the Jews". For more on the violence at Vilnius University in 1931, see (Aleksiun, 2020).

4 Those leaflets were evidence in the other trial of Władysław Wiszniewski, Franciszek Wiszniewski, Władysław Naborowski, and Bolesław Ostanówko, who were charged again with antisemitic and, surprisingly, anti-police violence committed in November 1937. The indictment pointed out that there was another trial being held at the same time, in which most of the defendants were the same people.

5 The "Aryan paragraph" was a provision in the statute (constitution) or regulations of an organization (academic club, sports club, union, business enterprise, trade guild) excluding Jews from membership. In the first years of the functioning of the university, only academic associations related to the Endecja (the national camp) included such a paragraph in their statutes. In the second year of the reborn university (1920), the largest mutual aid association, the Bratnia Pomoc Polskiej Młodzieży Akademickiej (Brotherly Help of the Polish Academic Youth), introduced a provision that excluded Jews, which forced them to establish their own association, called Stowarzyszenie Wzajemnej Pomocy Studentów Żydów (Association for Mutual Assistance of Jewish Students). The "Aryan paragraph" concerned not only the students who considered themselves Jews, but gradually also baptized persons with Polish identities, whose parents or grandparents were Jews.

6 Sejm Archives, AS, Kol.-T72/0073/01-07. 
the Jewish population of the city safe. In the report" on "incidents" that Rector Jakowicki sent to Minister Świętosławski, the main emphasis was put on the violence that occurred inside university buildings. He omitted the fact that the students were also responsible for organizing marches through the city and for riots in the part of the city which was inhabited mostly by the Jewish people.

On 12 November, after a series of assaults in university buildings, riots moved to the city. In response to the violence that had occurred at the university, and decreasing sense of security, the rector decided to close it. The report on the events addressed to Minister Świętosławski does not contain any information about what had happened on the same days outside the university, but we can find some information in the press reports, which tried to convey the terror and seriousness of the situation. ${ }^{8}$ There were spontaneous acts of violence in different parts of the Old and New Town, inspired and committed by university students:

Last night [12/13 November], [...] Rachmiel Werolownik [...] came to the emergency room with head injuries. He claims that in Kijowska Street [today Kauno] he was attacked by a group of young people, students, who severely beat him with sticks and brass knuckles. [...] Yesterday evening, an 18-year-old sales assistant, Abe Tejtelbaum [...] came to the emergency room again [...] and stated that in Wileńska Street [today Vilniaus], next to the Dincesa store, he had been hit on the head with his cane by the passing students. (A.G., 1936, p. 5)

The editorial office of the Wilner Tog was also attacked. It was the first of the two attacks on the Yiddish daily:

Several windows were broken in the editorial office. [...] The owner of the printing house, A. Szwajlich, a 56-year-old printer, was there when they entered the editorial office of the Tog [...]. Szwajlich tried to resist but was mercilessly beaten. Interviewed by the police, he said that he had been beaten with walking sticks and brass knuckles. He suffered a number of injuries and was taken to emergency, where he was given first aid. (A.G., 1936, p. 5)

The occupation of the Christian students' dormitory at Bouffałowa Street (or rather a demonstration of solidarity with the protesters demanding the introduction of "ghetto benches") echoed in both Polish and Yiddish daily press. The gathering in front of the dormitory when the demonstrators were leaving after the occupation (which had begun on

7 LCVA, F. 175, ap. 1(I)A, b. 545, k. 1-16.

8 And the city was overwhelmed with anti-Jewish violence: "Around 6 p.m. in Mickiewicza Street [today Gedimino], numerous groups of students began to gather on the sidewalks. According to the estimates of the authorities, about 200-250 students from the Endecja gathered on the sidewalks at that time and began 'raids' on cafés. Incidents like the one in the café Czerwony Sztrall, which we reported yesterday, where Jewish customers were ordered to leave the premises and the youth anthem was sung to the revolutionary tune of "Warszawianka", repeated in the cafés Czerwony Sztrall, Zielony Sztrall and at Rudnicki's, and then a crowd of students went along the sidewalks of Mickiewicza and Zamkowa streets [today Piliès] to Wielka Street [today Didžioji], where at Sawicz Street [today Savičiaus] they were dispersed by the police" (A.G., 1936, p. 5). 
14 November) turned into a hunger strike that continued for a few days. ${ }^{9}$ The Vilnius occupation of 1936 is the most well-known occupation of academic property in the interwar period. The protest resulted in similar occupations in Warsaw, Kraków and Lviv, and had a significant influence on the rector's decree on "ghetto benches".

The event described below is the departure of the students after the end of the protest, at the stage when the negotiations on spatial segregation in lecture halls were still ongoing, and when the Ministry of Religious Denominations and Public Education was working on an amendment to the law on higher education which would soon allow rectors to introduce "ghetto benches" at universities. Kurjer Wileński, one of the biggest and the most important daily newspapers issued in Polish, worded its report on this show of support to and solidarity with the protesters as follows:

About several hundred people moved to Bouffałowa Street [today Tauro] towards Mickiewicza Street [today Gedimino]. At the intersection of Portowa Street [today Paménkalnio] and 3 Maja Street [today Vasarios 16-osios], the crowd was partially dispersed. Nevertheless, several hundred people managed to get to Mickiewicza Street. (A.G., 1936, p. 5)

This description shows the strength and determination of the protesters. The quote above also shows their will to demonstrate their strength by marching to the university not the shortest way, but choosing the main representative street with luxury stores and cafés. From Mickiewicza Street (today Gedimino prospektas) they headed to the Cathedral Square, and then to Zamkowa (today Piliès gatvè). As anticipated, the crowd passed the university, and started to split into smaller groups. The pogrom atmosphere was not only perceptible, but grew stronger with every minute. A bit further we can read as follows:

The crowd kept shouting anti-Jewish slogans and moved along the sidewalks of Zamkowa and Wielka [today Piliess and Didžioji] streets [...]. At one point, there was a clink of glass. It was near the Dincesa store at the intersection of Wielka and Szwarcowy [today Švarco] streets. Someone threw a stone [...]. The first stone was a signal, and then more stones were thrown into other windows. Some premises were vandalized. Some rascals looted goods from broken shop windows. $[\ldots]$

Most windows in Wielka Street were broken. One of the shopkeepers, Rozenkranc, fought for his windows against a group of fifteen people for several minutes. Eventually, he was beaten. His windows were also broken. In Niemiecka Street [today Vokečiul, a very large number of windows were broken, including large exhibition windows on the premises of Fin, Chonowicz, Arkuski, Noza, Futropol and many others. In Mickiewicza Street [today Gedimino], windows were broken in Banuński's and Prużan's shops, in several cafés, etc. (A.G., 1936, p. 5)

9 The occupation of the dormitory ended on 22 November, following Archbishop Romuald Jałbrzykowski's negotiations with the protesters on the site. The end of the occupation involved a demonstration on leaving the building. In the evening of the same day, the windows of the rector's private house were broken. The occupation was so widely commented on that it even occasioned a parliamentary interpellation by pro-government MP Władysław Wojtowicz, who claimed that "[...] Fr. Grams, [...] instead of giving a lecture on ethics [to gymnasium students], began to praise the students who were blocking the dormitory in Vilnius at the time. Fr. Grams called them 'heroes', and he made a passionate appeal that the youth in the gymnasium should follow their example, because, as he claimed, the Jews should be stopped, and they should be removed and boycotted" (Sejm Archives, AS, Kol.-T73/0143/01-03). 
The pogrom crowd was growing stronger and marched through the city smashing shop windows. The glass was spread all over Niemiecka Street (today Vokečiu). Christian students only took Jewish businesses and houses as their targets. One of the strategies to avoid harm and assault, which a few years later became the main strategy to stay alive, was to hide. Christian academic youth became such a big threat for the Jews of Vilnius that hiding was usually the only way to save one's own health and life. A day later, the editors of Kurjer Wileński summed up the events with a short paragraph: "The rest of the day passed calmly. The streets were empty, especially in the Jewish quarter" (A.G., 1936, p. 5). This not so much marks the end of violence but indicates the level of terror against the Jewish inhabitants of the city.

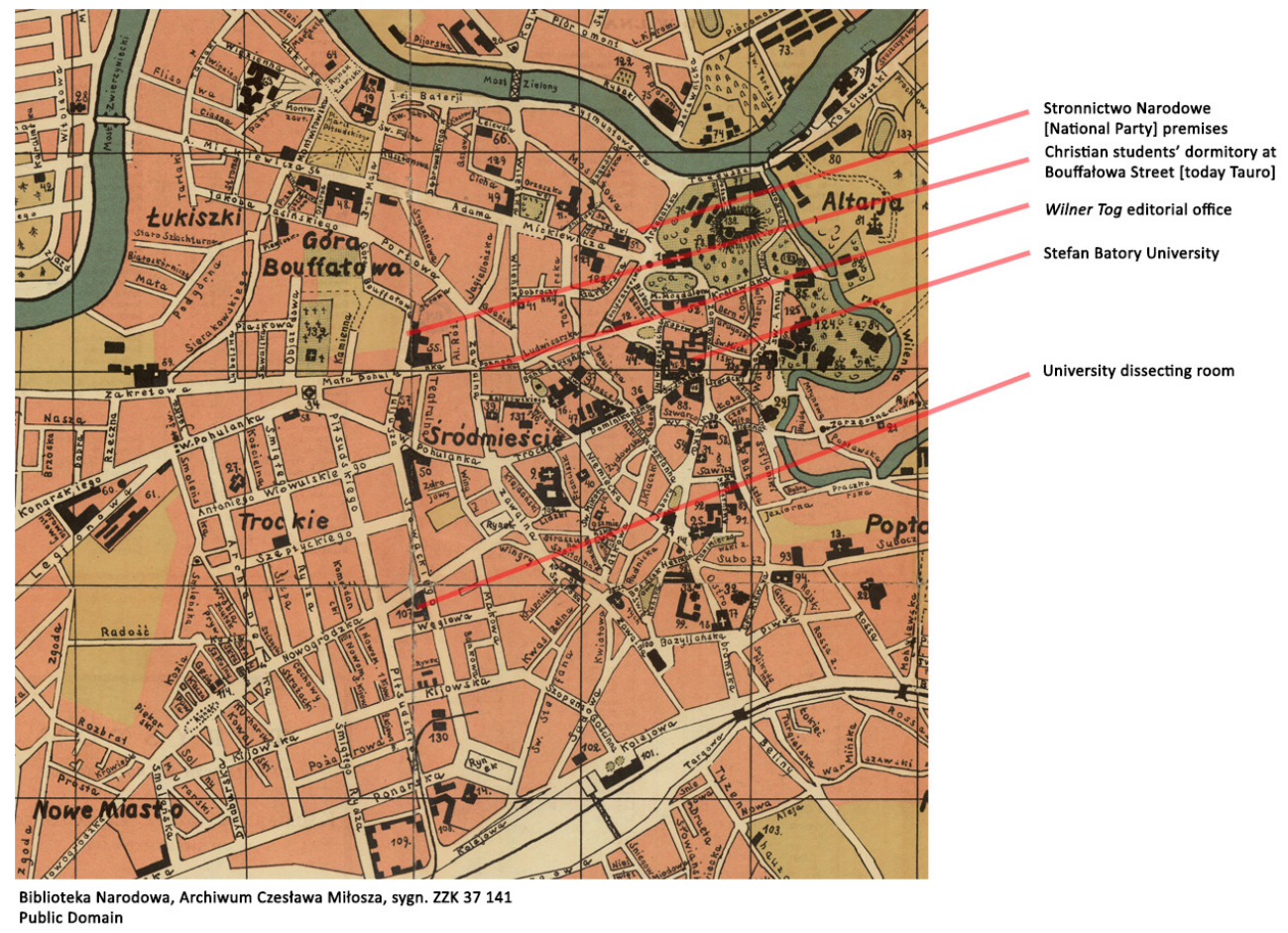

Fig. 2. Key sites of antisemitic violence on the city map from 1936.

\section{The Bombers}

In February, when the university reopened, numerous manifestations of antisemitic violence occurred. Students who were ethnic Poles tried to prevent Jewish students from entering lecture halls, and even if the latter succeeded in getting through, they encountered spontaneous "ghetto benches". As a result, Jewish students were forced to sit on the left side of lecture halls or, if they refused, they were assaulted and pushed out to the corridors. Moreover, Jewish students were attacked, and some of the academics did not 
give lectures due to what was described as "demonstrative behavior of Jewish students". Following the arrest of some Poles for the anti-Jewish violence of November 1936, the university opened disciplinary proceedings against four of them who were students. The Academic Court acquitted two of them, one received a deferred sentence, and one, Zbigniew Nanowski, ${ }^{10}$ a member of the Młodzież Wszechpolska (All-Polish Youth), ${ }^{11}$ was expelled for a year. The trial was held on 18 March 1937 in the morning. On the same day in the evening, a delegation of the Młodzież Wszechpolska appeared in the rector's private apartment demanding that Nanowski's punishment be mitigated. When the rector refused, the delegates left. A connection between this event and the explosion that followed will be shown below.

One of the bombs planted during the first three months of 1937 targeted Professor Konrad Górski, who was in charge of the SBU Academic Court. In his letter to Minister Świętosławski the rector reports:

The bomb was exceptionally strong and caused damage to the stairway and blew up the door. Later I was informed by the administrative authorities and the Prosecutor's Office that immediately after the blast a group of students, including several members of the Polesia corporation, circled around the site of the attack and indulged in jokes at the security authorities, shouting "go out on a wild goose chase". ${ }^{12}$

Professor Górski commented on the situation in the local press on 21 March. In the article entitled "Was I Tolerant?" (Górski, 1937)' he refers not only to the issue of planting a bomb at the door of his apartment, which was strictly connected with Nanowski's trial and the visit of the representatives, but also to the presence of Jews at universities as well as in the cultural and economic life of the Second Polish Republic in general. With a moral superiority, specific for his social position as a university professor, he comments on Nanowski's disciplinary trial, explaining motivations related to the sentence as follows:

10 Zbigniew Nanowski (1916-2006) was a law student at SBU from 1934. In 1937, after being brought to disciplinary court for violence against Jewish students, namely beating them on the back with a truncheon, he moved to the University of Poznań, where he studied until 1939. After the war, he completed his law studies in Toruń. He participated in the September campaign in 1939, was a member of the Home Army, and took part in the Warsaw Uprising of 1944. He was also the initiator of building a monument on Roman Dmowski's grave at the Bródno cemetery in Warsaw. During his studies at SBU, Nanowski was a member of the Polesia student corporation, a board member of SBU Law Society, a member of the Młodzież Wszechpolska (All-Polish Youth) and the Stronnictwo Narodowe (National Party). I based his biographical profile on information from the archives of the Polesia corporation. Nanowski stated that during the November 1936 ani-Jewish riots he was innocent, but Professor Górski, the judge of the Academic Court saw the situation otherwise: "The best, however, was the answer of Nanowski himself to the question whether he admitted to the alleged act of beating Jews in the Skarga courtyard on 8 February this year. He replied, 'I don't remember such a fact.' Imagine that someone innocent is accused of a robbery committed on a specific date and in a specific place; if it is an innocent man, he will say: I have never robbed anyone, but he will not say that he does not remember it, because that would be an admission that he once did, but not at that time and not in that place. It is hard to fall lower than by saying this" (Górski, 1937, p. 2).

11 Młodzież Wszechpolska (1934-1937) - Polish academic ideological nationalist organization formed after the Obóz Wielkiej Polski (Camp of Great Poland) was banned. Following the bombings in Vilnius, the Młodzież Wszechpolska was also banned as some of its members had been involved in the attacks.

12 LCVA, F. 175, ap. 1(I)A, b. 545, k. 39. 
Initially, it was just about visiting the Department of Physical Chemistry, but then new incriminating materials were added, of which the university authorities did not make a separate case but instructed me to treat everything as one case. The incident at the Department of Physical Chemistry was of minor importance, the suspicions of Nanowski's participation in the attack on the Department of Classical Philology and the University Library were not confirmed in the course of the judicial investigation, but the fact of his participation in the gang that on 8 February blocked the main entrance to the university in order to prevent Jews from coming in was confirmed by Nanowski's own admission. Even more serious is the fact that on that occasion Nanowski was beating Jews who were trying to get into the building, that he beat them with a club, attacking them from behind; a fact confirmed by an utterly credible person. I emphasize the issue of credibility, because witnesses appearing in disciplinary courts do not take an oath and the judge must form an opinion as to their credibility on the basis of the wording of the testimony itself; the immaculate past of the witness himself is also of great importance here. (Górski, 1937, p. 1)

As a lawyer, Górski paid attention to the truthfulness of the witness. In another part of his article he tries to show that for him it was Nanowski who was not credible during the disciplinary trial. Lack of truthfulness on the part of defendants also shows an ongoing crisis of the academic court system. Christian students knew that the only way to stay at the university and pursue their strategy of pushing Jewish people out of the academy was to lie or at least not to tell the truth. The description of different forms of violence against Jewish students shows not only the universality of antisemitic violence at the university, but also a full and complex awareness of those acts.

The incident which happened shortly afterwards provided new clues in the bombing investigation and made it possible to detain several suspects. Again, the rector's letter to the minister, in which the rector reports on the events of recent weeks, reads:

On Sunday, 21 March, a bomb exploded on Stronnictwo Narodowe [National Party] premises in Vilnius at 1, Mostowa Street [today Tilto]. The police did not know about this bomb and the case came out when a member of the Stronnictwo Narodowe by the name of Naborowski was brought to hospital wounded by the explosion. The same man, Naborowski, was visited in the hospital by a lady called Świechowska. Following her, the police found a bomb workshop located in her apartment at 62, Mickiewicza Street [today Gedymino], app. 7, that is, in the house where I also live. (Witold Staniewicz, LCVA, F. 175, ap. 1(I)A, b. 545, k. 39)

A few hours later several arrests were made, about which the rector also informed the minister in his letter. On 22 March 1937, the front page of Kurjer Wileński featured the article "Explosion in the Right Place: Firecracker on Stronnictwo Narodowe Premises" (Święcicki, 1937, p. 1). In the following days, the daily press published more information, including on the regulation issued by the Vilnius voivode, Ludwik Bociański, imposing a ban on the activities of Stronnictwo Narodowe in the Vilnius region ("Zakaz działalności Stronnictwa Narodowego", 1937, p. 1; [c], 1937, p. 2). The "Praca Polska" (Polish Labor) trade union was also banned for encouraging the economic boycott of Jews, and one issue of the daily newspaper Słowo, published by 
the Stronnictwo Narodowe, was seized on the grounds that it posed a threat to public order. A few weeks later, at the beginning of April, the Młodzież Wszechpolska and the Polesia student corporation were banned (Wojciech Świętosławski, LCVA, F. 175, ap. 15, b. 44, k. 104) by the Ministry of Religious Denominations and Public Education; the decision was announced by Rector Wiltold Staniewicz a few days later (Witold Staniewicz, LCVA, F.175, ap. 15, b. 44, k. 103). In a secret communication from a local government official to the rector we read that "as part of the investigation of the firecracker campaign in Vilnius, during the police search of Młodzież Wszechpolska's premises Vice-Prosecutor [...] seized many files; they were sent to the city hall" (Czernichowski, LCVA, F.175, ap. 15, b. 44, k. 102). It is worth pointing out that at the time both Zbigniew Nanowski and Jan Drawnel were members of the Młodzież Wszechpolska board.

\section{The Trial and the Sentence}

The trial of the bombers was held on 16 and 17 March 1938, one year after the events. Although it was covered in the Vilnius press, both Yiddish and Polish, it was not a front page topic. The day was dominated by the reports about the annexation of Austria into Nazi Germany a few days before, and the diplomatic crisis between Poland and Lithuania. In the dock were the members of a group that called themselves Północno-wschodnia grupa terrorystówantysemitów (The Northeast Group of Terrorists-Antisemites), as the letter sent ahead of the bomb blast outside Professor Górski's apartment was signed. They were charged with having planned and carried out fourteen explosions (see [w], 1938a, p. 5, 1938b, p. 5; "Wyrok w procesie o zamachy petardowe w Wilnie", 1938, p. 4). ${ }^{13}$ However, in the absence of the two key defendants - Alicja Olszewska and her son Waldemar, a former SBU student - the court decided to separate their case. A few years earlier, Waldemar Olszewski had been sentenced by a court in Vilnius for antisemitic violence and consequently expelled from university. According to the Kurjer Wileński press report, the absence of the two key defendants was caused by the hospitalization of Alicja Olszewska and the lung treatment that Waldemar Olszewski was undergoing in Yugoslavia ([w], 1938b, p. 5). Separating those two cases resulted in a new line of defense of the other accused persons: pushing the blame on Olszewska as far as possible. The defense counsel took advantage of her absence to present her as a "boss of the group" who "manipulated young minds", while her son's guilt was blurred.

Pushing all the blame on her also resulted in a very thick and convincing narration. Olszewska was the oldest and was the mother of one of the attackers, so it automatically located her on another, higher social level. She was described as a manipulative individual ("Wyrok w procesie o zamachy petardowe w Wilnie", 1938, p. 4) and a lady ([w], 1938a, p. 5), a woman who possessed others' free will like a demon. Framing Olszewska as the brain of the operation not only framed her during the trial, but also exonerated other defendants.

13 During the trial, it was discovered that seventeen bombs had been produced, out of which 14 actually exploded. 
The rest of the Northeast Group of Terrorists-Antisemites received the following sentences: Maria Świechowska, an unemployed teacher and a former SBU student - two and a half years in prison, Władysław Naborowski, the one who accidentally detonated the bomb in the office of Stronnictwo Narodowe - one year and a half, Bolesław Ostanówko - one year, Albert Kropiwnicki - one year. Jan Drawnel and Zygmunt Kurczewski were acquitted ([w], 1938b, p. 5). Jan Drawnel, an SBU student, had been previously charged with a similar bombing operation in Vilnius in 1934, along with Waldemar Olszewski. Then, the only target was the synagogue at Popławska Street (today Paupio). Drawnel was acquitted due to lack of evidence, but Olszewski was found guilty and was expelled from university. In November 1936, Drawnel was involved in violence at the university and in vandalizing and looting Jewish shops during antisemitic riots in the city. Then he was sentenced by a court in Vilnius to six months' imprisonment for breaking windows in a Jewish shop; at university, he only got an admonition from the dean.

\section{Conclusions}

Interwar Wilno (now Vilnius) was not a culturally, nationally, ethnically, class-wise, and religiously homogeneous city as it is described today. For decades, the memory of the interwar period has been processed, rewritten, overwritten, and erased in the literature and by cultural practices. ${ }^{14}$ Since the end of World War II, this system of reiteration has not only produced (Weeks, 2015), but also replicated the image of Polishness of the region. In Polish historiography, the takeover of Vilnius by Poles is called a "conflict" or "dispute" (Łossowski, 1996, pp. 13-16), while in Lithuanian works it is the beginning of an occupation (Balkelis, 2019; Žepkaité, 1986, pp. 46-47). Despite the post-Holocaust discreditation of the category of "ethnically Polish lands", it is constantly used by Polish historians to describe the interwar Vilnius region (Chwalba, 2019; Łossowski, 1996). It is also seen in the category of "Kresy" (Borderlands). ${ }^{15}$ As various sociolinguists point out, this

14 Nostalgia for the cities that were part of interwar Poland and are now outside Polish borders is visible in many contemporary works. The authors writing about the geography and topography of such cities as Vilnius, Lviv, or Grodno do not use present-day street names. Instead, they still use former Polish names, as if a given city was still within the borders of Poland. Undoubtedly, the book by Waldemar Wołkanowski is an exception: the author not only lists the current street names in Vilnius, but also updates the numbering of buildings (see Wołkanowski, 2019). A separate, equally interesting space serving both to maintain and to generate the Polish identity of cities located within the borders of interwar Poland, and now located outside its borders, are social media pages. In the descriptions of the websites, the authors not only emphasize the past Polishness of these places, but also indicate that this Polishness is being erased by the contemporary owners of the space. The Facebook page aptly named "Polish City of Lwów [Lviv]" can serve as an example of this phenomenon. In the information section about the site, the authors post notes in two languages (Polish and, interestingly, Russian), and write: "Lwów [Lviv] - the most beautiful and the most Polish of all Polish cities! Place - in which decisions important for Poland were made. Despite the partitions - you could always hear the Polish heartbeat here. [...] Ukrainians systematically remove Polish traces in this city, but Lwów [Lviv] will NEVER lose its Polishness anyway. These houses, the Opera House, and cultural monuments will always remind us of Poland!" (capitalization as in original). 15 The name "Kresy" does not have a long tradition of use in the Polish language. It was introduced by the poem Mohort by Wincenty Pol, published in 1855 (cf. Sawaniewska-Mochowa, 2016). 
is associated with nostalgia - the category of "Kresy" deviated from its original, emotionally undistorted meaning, gaining the function of organizing and producing the Polish memory of the region (Gocót, 2020, pp. 85-86; Sawaniewska-Mochowa, 2016, pp. 249-251).

For Roberta Senechal de la Roche, terrorism is one of the four types of collective violence (Senechal de la Roche, 1996, pp.102-105): "an organized form with collective liability", the remaining three being lynching, rioting, and vigilantism. The bombings in Vilnius in early 1937 were organized by a group. The pogrom-like antisemitic violence was a characteristic act of exclusion of Jewish students from the university. The series of bomb attacks conducted for almost two months not only changed the scale of violence, but also showed the radicalization of attitudes. One of the places where the terrorist group recruited their members was the university.

The lack of Jewish testimonies in archives shows one more thing: another step of exclusion. As Michel-Rolph Trouillot points out, those who are in power decide what is worth remembering and what is trivial (Trouillot, 1995, p. 115). Trivialization of the violence against Jewish people in Vilnius before the Holocaust is visible not only in the trivial language used by the majority to describe acts of terror and violence, but also in the absence of first person narratives in police records or other official documents. This type of exclusion visualizes ${ }^{16}$ the tension between representation and narration. Exclusion also produces ability to project relevance (Trouillot, 2002, p. 221), which takes part in the blurring of the interpretations other than major. As a consequence, we deal with an idealized caption of a majority vision rather than a realistic picture of the past.

\section{References}

\section{Archival sources}

Lietuvos centrinis valstybės archyvas (Lithuanian Central State Archives)

LCVA, F. 89, ap. 5, b. 221

LCVA, F. 129, ap. 2, b. 1296

LCVA, F. 175, ap. 1(I)A, b. 505

LCVA, F. 175, ap. 1(I)A, b. 545

LCVA, F. 175, ap. 15, b. 44

Archiwum Sejmowe (Sejm Archives)

AS Kol.-T73/0143/01-03

16 As Trouillot states, this visualization can be seen in four moments: (1) the moment of fact creation (the making of sources); (2) the moment of fact assembly (the making of archives); (3) the moment of fact retrieval (the making of narratives); (4) the moment of retrospective significance (the making of history in the final instance). I would like to thank Natalia Aleksiun, Ewa Wróblewska-Trochimiuk and Karolina Ćwiek-Rogalska for their comments and suggestions. 


\section{Literature}

Aleksiun, N. (2012). Jewish students and Christian corpses in interwar Poland: Playing with the language of blood libel. Jewish History, 26(3-4), 327-342. https://doi.org/10.1007 /s10835-012-9163-5

Aleksiun, N. (2014). Together but apart: University experience of Jewish students in the Second Polish Republic. Acta Poloniae Historica, 109, 109-137. https://doi.org/10.12775 /APH.2014.109.06

Aleksiun, N. (2016). The cadaver affair in the Second Polish Republic: A case study of practical antisemitism? In R. Fritz, G. Rossoliński-Liebe, \& J. Stárková (Eds.), Alma mater antisemitica: Akademisches Milieu, Juden und Antisemitismus an den Universitäten Europas zwischen 1918 und 1939 (pp. 203-220). new academic press.

Aleksiun, N. (2020). Studenci z pałkami: Rozruchy antyżydowskie na Uniwersytecie Stefana Batorego w Wilnie. In K. Kijek, A. Markowski, \& K. Zieliński (Eds.), Pogromy Żydów na ziemiach polskich w XIX i XX wieku: Vol. 2. Studia przypadków (do 1939 roku) (pp. 327-370). Instytut Historii im. Tadeusza Manteuffla PAN; Instytut Historyczny UW; Uniwersytet Warmińsko-Mazurski; Uniwersytet Wrocławski; Muzeum Historii Żydów Polskich POLIN; Uniwersytet Marii Curie-Skłodowskiej w Lublinie.

Balkelis, T. (2019). Lemtingi metai. Lietuva 1914-1923 m. Karas, revoliucija ir tautos gimimas. Tyto alba.

Chwalba, A. (2019). 1919: Pierwszy rok wolności. Wydawnictwo Czarne.

Gocół, D. (2020). Obraz Kresów Wschodnich w tekstach historii mówionej. Acta BalticoSlavica, 44, 85-103. https://doi.org/10.11649/abs.2020.004

Górski, K. (1937, March 21). Czy byłem tolerancyjny? Słowo, 16(79), 1.

Judzińska, N. (2020). "Odmowa ta spowodowała zajście": Sprawa dyscyplinarna Rywki Profitkier a "getto ławkowe". In K. Slany, J. Struzik, B. Kowalska, M. Ślusarczyk, M. Warat, E. Ciaputa, E. Krzaklewska, A. Król, \& A. Ratecka (Eds.), Utopie kobiet: Sto lat praw wyborczych kobiet (1918-2018) (pp. 155-173). Wydawnictwo Uniwersytetu Jagiellońskiego.

Łossowski, P. (1996). Konflikt polsko-litewski 1918-1920. Książka i Wiedza.

Mrzygłód, I. (2021). The cult of the martyr: The symbol of Stanislaw Wacławski and rituals of violence in Warsaw student milieu of the 1930s. Sprawy Narodowościowe: Seria nowa, 2021(53), 1-24. https://doi.org/10.11649/sn.2545

Natkowska, M. (1999). Numerus clausus, getto ławkowe, numerus nullus, "paragraf aryjski": Antysemityzm na Uniwersytecie Warszawskim 1931-1939. Żydowski Instytut Historyczny. Rudnicki, S. (1993). From "numerus clausus" to "numerus nullus". In A. Polonsky (Ed.), From shtetl to socialism: Studies from "Polin" (pp. 359-382). Liverpool University Press; Littman Library of Jewish Civilisation.

Rudnicki, S. (2008). Równi, ale niezupełnie. Biblioteka Midrasza.

Sawaniewska-Mochowa, Z. (2016). Kresy w różnych perspektywach oglądu. In M. Krajewska, J. Kulwicka-Kamińska, \& A. Szulc (Eds.), Święte księgi judaizmu, chrześcijaństwa i islamu w słowiańskim kręgu kulturowym: Prace dedykowane Profesorowi Czesławowi Łapiczowi (pp. 243-260). Wydawnictwo Uniwersytetu Mikołaja Kopernika. 
Senechal de la Roche, R. (1996). Collective violence as social control. Sociological Forum, 11(1), 97-128. https://doi.org/10.1007/BF02408303

Senechal de la Roche, R. (2004). Toward a scientific theory of terrorism. Sociological Theory, 22(1), 1-4. https://doi.org/10.1111/j.1467-9558.2004.00199.x

Srebrakowski, A. (2018). Zamachy petardowe w Wilnie, w 1937 roku: Kronika dokumentalna. In T. Głowiński (Ed.), Z Jeleniej Góry do Wrocławia i z powrotem: Wokół historii społecznej i gospodarczej (pp. 256-277). Wydawnictwo Tum Wrocławskiej Księgarni Archidiecezjalnej. Tokarska-Bakir, J. (2012). Okrzyki pogromowe: Szkice z antropologii historycznej Polski lat 1939-1946. Wydawnictwo Czarne.

Tokarska-Bakir, J. (2017). Pogrom cries - Essays on Polish-Jewish history, 1939-1946. Peter Lang. https://doi.org/10.3726/b11561

Tokarska-Bakir, J. (2018). Pod klątwa: Społeczny portret pogromu kieleckiego (Vol. 1). Czarna Owca. Trouillot, M.-R. (1995). Silencing the past: Power and the production of history. Beacon Press. Trouillot, M.-R. (2002). The otherwise modern: Caribbean lessons from the savage slot. In B. M. Knauft (Ed.), Critically modern: Alternatives, alterities, anthropologies (pp. 220-237). Indiana University Press.

Turner, V. (1974). Dramas, fields, and metaphors: Symbolic action in human society. Cornell University Press.

Weeks, T. R. (2015). Vilnius between nations, 1795-2000. Northern Illinois University Press. Wołkanowski, W. (2019). Wileńskie ABC: Ludzie-miejsca-historie. Art-Print. Žepkaitè, R. (1986). Lietuva ir Didžiosios Valstybès 1918-1939 m. Šviesa.

Żyndul, J. (1994). Zajścia antyżydowskie w Polsce w latach 1935-1937. Fundacja im. K. KellesKrauza; Scholar.

\section{Newspapers}

A.G. (1936, November 14). Uczelnia zamknięta - zajścia trwają. Kurjer Wileński, 5.

[c]. (1937, March 24). Opieczętowanie lokali Stronnictwa Narodowego. Zwolnienie części aresztowanych i nowy zamach bombowy. Kurjer Wileński, 2.

Proces bombiarzy endeckich. Czterej oskarżeni skazani na więzienie. (1938, March 18). Kurjer Powszechny, 3.

Proces o zamachy petardowe. Anonim "Północno-wschodniej grupy terrorystów-antysemitów". (1938, March 17). Wieczorna Gazeta Wileńska, 4.

Święcicki, J. (1937, March 22). Eksplozja we właściwym miejscu: Petarda w lokalu Stronnictwa Narodowego. Kurjer Wileński, 1.

[w]. (1938a, March 17). Dama z towarzystwa na czele terrorystów. Sprawcy 14 zamachów petardowych przed sądem. Kto spowodował wybuchy koło mieszkań posła rabina Rubinsztejna i profesora Górskiego. Kurjer Wileński, 5.

[w]. (1938b, March 18). Wyrok w procesie petardowym w Wilnie. Obrona w procesie terrorystów endeckich "staje na rzęsach" dążąc do wybielenia Stronnictwa Narodowego. Kurjer Wileński, 5. 
"wu". (1936, November 13). Na U.S.B. wykłady zawieszone. Zajścia antyżydowskie na wszystkich wydziałach. Dziennik Wileński, 2.

Wyrok w procesie o zamachy petardowe w Wilnie. (1938, March 18). Wieczorna Gazeta Wileńska, 4.

Zakaz działalności Stronnictwa Narodowego. (1937, March 24). Kurjer Wileński, 1. [א]. (1937, January 19). Di bombe in "Wilner Tog" un ojf brejter gas. Wilner Tog, 1.

\title{
Bomby w Wilnie. Radykalizacja postaw i praktyk antysemickich przed II wojną światową
}

\begin{abstract}
Abstrakt
W przededniu Zagłady przez Polskę przetacza się fala przemocy antysemickiej o charakterze pogromowym, która widoczna jest w niemalże każdym aspekcie życia codziennego. Niniejszy artykuł przedstawia analizę aktów i działań antysemickich, które zdarzyły się w Wilnie pod rządami polskimi. Na początku roku 1937 miasto zmierzyło się z serią zamachów bombowych. Chociaż omówiona przemoc osadzona jest w kontekście sytuacji w innych miastach, pozostaje jednak i przykładem, i swoistym wzorem bezwarunkowej radykalizacji nacjonalistycznych postaw i praktyk wśród nieżydowskich Polaków i Polek pochodzących z różnych klas i warstw społecznych. Autorka koncentruje się w badaniach głównie na udziale studentów - przyszłych członków inteligencji - w tym „festiwalu przemocy" i analizuje opisywane wydarzenia w ramach koncepcji pogromu oraz Turnerowskiego dramatu społecznego.

Słowa kluczowe: antysemityzm; ruch skrajnie prawicowy; terroryzm; uniwersytet; przemoc zbiorowa; okres międzywojenny
\end{abstract}

\section{Citation}

Judzińska, N. (2021). Bombs in Vilnius: Radicalization of antisemitic attitudes and practices before World War II. Sprawy Narodowościowe: Seria nowa, 2021(53), Article 2500. https://doi.org/10.11649/sn.2500 